\title{
UDC 621.311:621.882.626
}

\section{SERVICEABILITY RESTORATION OF OPERATING FASTENING ELEMENTS OF THE HIGH PRESSURE CYLINDER BODY OF HPP STEAM TURBINES}

\author{
Lesya Svirska
}

\author{
Karpenko Physico-Mechanical Institute of the National Academy of Sciences of \\ Ukraine, Lviv, Ukraine
}

\begin{abstract}
Summary. The mechanical characteristics of the fastening nuts steel of the high-pressure cylinder (HPC) of the steam turbine of the heat power plant (HPP), operating under the influence of hard temperature-power conditions for $21 \times 10^{4}$ hours, are outside the limits of the regulated values. It is the indicator of steel degradation. Using different types of heat treatment $(H T)$, including recommended for $25 \mathrm{Kh} 2 \mathrm{MIF}$ steel in the initial state, made it possible (in a certain extent of course) to restore the properties of the metal used for fastening fittings. The obtained results substantiate the efficiency of using of the HT for restoring the mechanical characteristics of steel for nuts of the HPC of the steam turbine in order to prolong their service lifetime.

Key words: fastening nuts, metal degradation, structure parameters, characteristics of strength and plasticity, impact toughness, restoration of serviceability, heat treatment.
\end{abstract}

Introduction. Fasteners are used to connect the body parts of HPP steam turbines after their disassembling during scheduled or forced repairs [1]. During assembly operations the studs are mounted on their proper places in the case and the removable rotor case cover is attached to it by nuts in cold condition. The final tightening of nuts on studs with diameter more than $64 \mathrm{~mm}$ is carried out under the studs elongation control [2, 3].

During operation, the contact pressure in the connection of HPC case parts should be three times higher than the internal medium pressure. Initial stresses in studs, which provide satisfactory seal of the flange connection between the two body parts of modern steam turbines, reach $300 \mathrm{MPa}$ [4]. As a result the high tensile and bending stresses act on the fasteners, and their threads work in the shear mode $[3,5]$. It is clear that the high temperature and difficult operation conditions can cause their damage. A significant gradient of thermal stress during the start-stop of the technological process and the design features of the fastening elements determine high requirements to the properties of the steels for their manufacture. The stability of steel characteristics for these elements during long-term operation is of great importance since complex temperature-power conditions of their operation change the structure [6] and worsen the mechanical characteristics of heat-resistant steels $[7,8]$.

Overload of fasteners caused by unsuccessful constructive decision, which was not sufficient for optimal stress distribution between the mounting elements due to excessive distances between them, the high level of vibration and uncontrolled overload of elements due to non-compliance with regulatory requirements during installation and disassembling of the rotor body are listed among the fasteners damage causes. Therefore, the achievement of necessary body parts tightening does not lose its relevance today [9-11]. Taking into account the threatening consequences of the seal breaking in the flange connection of the HPC case parts [12], the leading manufacturers of power equipment and operators continue to pay particular attention to the fasteners reliability $[13,14]$.

The objective of the paper is to estimate the mechanical characteristics of steel $25 \mathrm{Kh} 2 \mathrm{M} 1 \mathrm{~F}$ from the nut operated in the HPC of the steam turbine in comparison with its 
regulated values, to reveal structural features of its operational degradation and to substantiate the possibility of the following operation of similar nuts after their repeating heat treatment for structure and mechanical characteristics restoration of steel.

The object and methods of investigation. The heat-resistant steel $25 \mathrm{Kh} 2 \mathrm{M} 1 \mathrm{~F}$ from the nut, used for connection of two HPC case parts of HPP steam turbine was investigated. Assuming that the pressure and temperature in HPC change linearly (from $24 \mathrm{MPa}$ and $540^{\circ} \mathrm{C}$ at the level of the first stud to $6,2 \mathrm{MPa}$ and $360^{\circ} \mathrm{C}$ at the eleventh level), and the distance between the studs in the case is approximately the same, it was supposed that in the level of the investigated (ninth) stud the pressure and the temperature were $\sim 10 \mathrm{MPa}$ and $\sim 450^{\circ} \mathrm{C}$ respectively. Under these conditions, the tested nuts operated for $21 \cdot 10^{4}$ hours before they were damaged. The chemical composition of steel $25 \mathrm{Kh} 2 \mathrm{M} 1 \Phi$ of the analyzed nut is given in Table 1 .

\section{Table 1}

The chemical composition of the investigated $25 \mathrm{Kh} 2 \mathrm{M} 1 \mathrm{~F}$ steel, mass. $\%$

\begin{tabular}{|c|c|c|c|c|c|c|c|c|c|c|}
\hline Element & $\mathrm{C}$ & $\mathrm{Cr}$ & $\mathrm{Mo}$ & $\mathrm{V}$ & $\mathrm{Ni}$ & $\mathrm{Si}$ & $\mathrm{Mn}$ & $\mathrm{Cu}$ & $\mathrm{S}$ & $\mathrm{P}$ \\
\hline Nut & 0,26 & 2,1 & 0,9 & 0,4 & 0,3 & 0,31 & 0,54 & 0,13 & 0,004 & 0,027 \\
\hline $\begin{array}{c}\text { Content } \\
\text { according } \\
{[15]}\end{array}$ & $0,22-0,29$ & $2,1-2,6$ & $0,9-1,1$ & $0,3-0,5$ & $\begin{array}{c}\text { до } \\
0,25\end{array}$ & $0,17-0,37$ & $0,4-0,7$ & 0,13 & до 0,025 & $\begin{array}{c}\text { до } \\
0,03\end{array}$ \\
\hline
\end{tabular}

The mechanical characteristics of steel $25 \mathrm{Kh} 2 \mathrm{M} 1 \mathrm{~F}$ are specified before its release to service [5] and at the beginning of nut operation are given in Table. 2

Table 2

Mechanical properties of $25 \mathrm{Kh} 2 \mathrm{M} 1 \mathrm{~F}$ steel from the nut in the initial state

\begin{tabular}{|c|c|c|c|c|c|c|}
\hline \multirow{2}{*}{ In the initial state } & $\sigma_{Y T S}, \mathrm{MPa}$ & $\sigma_{U S}, \mathrm{MPa}$ & $\delta, \%$ & $\psi, \%$ & $\mathrm{HB}$ & $\mathrm{KCU}, \mathrm{MJ} / \mathrm{m}^{2}$ \\
\cline { 2 - 6 } & 824 & 765 & 18 & 66 & 242 & 0,85 \\
\hline $\begin{array}{c}\text { According to specifying } \\
\text { document [15] }\end{array}$ & $\geq 785$ & $667 \ldots 785$ & $\geq 17$ & $\geq 65$ & $197 \ldots .229$ & 0,5 \\
\hline
\end{tabular}

Characteristics of strength and plasticity of steel $25 \mathrm{Kh} 2 \mathrm{M} 1 \Phi$ were determined on smooth cylindrical five-fold samples with $5 \mathrm{~mm}$ diameter of axial orientation according to GOST 1497-84 [16]. The samples were tested on the tensile machine UME-10T at the sample deformation rate $3 \cdot 10^{-3} \mathrm{~s}^{-1}$.

The hardness of $H B$ steel was measured on the flat parallel grinding sample in radial section of the nut on TK-2 device under the load on indenter $750 \mathrm{H}$ in accordance with GOST 9012-59 [17].

The impact strength of steel was determined on the axial Mesnager samples according to GOST 9454-78 [18]. The tests were carried out on pendulum impact machine IO-5003.

For metalographic and fractographic investigations of heat-resistant of the $25 \mathrm{Kh} 2 \mathrm{M} 1 \mathrm{~F}$ steel, the optical microscope Neophot-21 and scanning electron microscope EVO-40XVP were used.

Analysis of HPC damaged nut of HPP steam turbine. A large number of radial cracks (Fig. $1 a$ ) were observed on the operated nut. They propagated from the thread, i.e. from the surface, which during steam turbine HPC operation was in direct contact with studs. This gave grounds for association of these cracks with thermal fatigue [19].

Fractographic investigation of nut fracture at low resolution revealed the smooth relief in the area of thermal fatigue crack origin and viscous relief in the complete breaking area 
(Fig. $1 b$ ). At the highest resolution (Fig. $1 c$ ), in the local areas of crack origin, the throughgrain quasisplitting character of the fracture caused by thermal fatigue was defined.
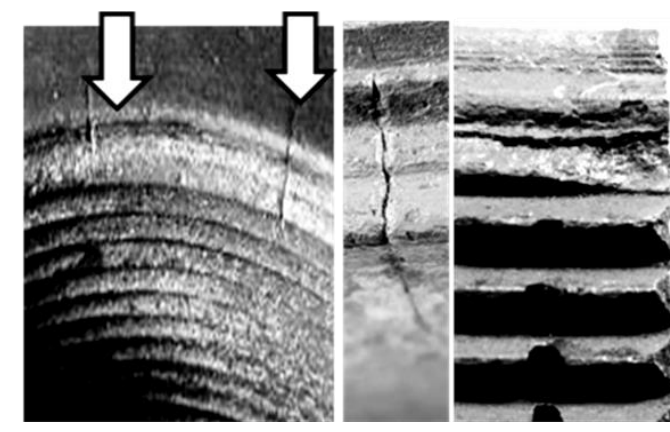

$a$

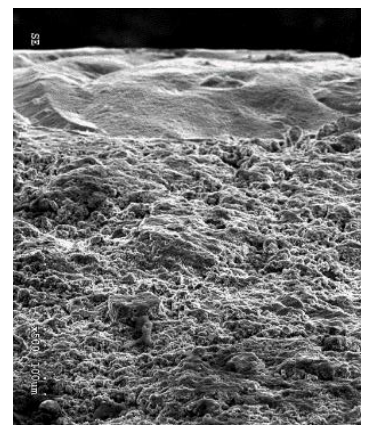

$b$

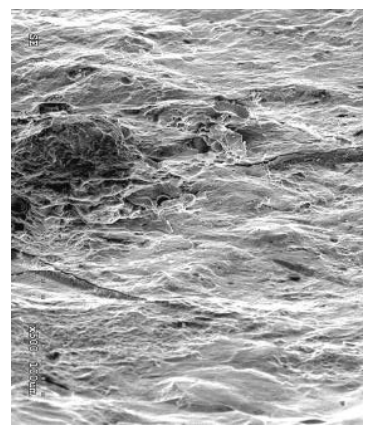

c

Figure 1. Thermal fatigue cracks from the internal thread on the nut $(a)$ and the features of its fracture surface formed during operation in the high-pressure cylinder case of HPP steam turbine at the lower $(b)$ and higher (c) of microscope resolutions

The nut operated for $\sim 21 \cdot 10^{4}$ hours at temperature $450^{\circ} \mathrm{C}$ and under high operating loads, which contributed to the structure degradation of low alloyed heat-resistant steels associating with redistribution of carbon and doping elements [20-26]. Analysis of metallographic results showed that as the result, the ferrite-carbide structure was formed in the investigated steel after the operation. Most ferrite grains were of irregular shape, and their sizes varied in the range from $60 \mu \mathrm{m}$ to $150 \mu \mathrm{m}$. The carbides inside these grains were up to 0.5 microns in diameter, and along the grain boundaries up to $2 \ldots 3$ microns. Intensive separation of carbides along the grain boundaries and their coagulation reduced the content of the doping elements in solid solution resulting in worsening the characteristics of hightemperature function of heat-resistant steels. These structural features of operating steel were considered as the root cause of the decrease of steel resistance to the fatigue cracks origin and growth in HPC nuts of HPP steam turbine.

Nuts are rather expensive fastening elements, which does not contribute to their simultaneous replacement even in one unit. Therefore, there is the need for the possibility of extending the operating nuts lifetime of, in which no defects were determined by the nondestructive testing methods.

In order to substantiate the possibility of restoration of the of operating nuts, repeated samples heat treatment was used according to the modes shown in Fig. 2. For the nuts made of steel $25 \mathrm{Kh} 2 \mathrm{M} 1 \mathrm{~F}$, normalization and high tempering were used to provide necessary mechanical characteristics in the initial state. Therefore, normalization was also used for repeated HT. We tested three versions of steel normalization (from $960^{\circ} \mathrm{C}, 1050^{\circ} \mathrm{C}$ and dual from $1050^{\circ} \mathrm{C}$ and $960^{\circ} \mathrm{C}$ ), followed by their high temperature tempering at temperature $690^{\circ} \mathrm{C}$.
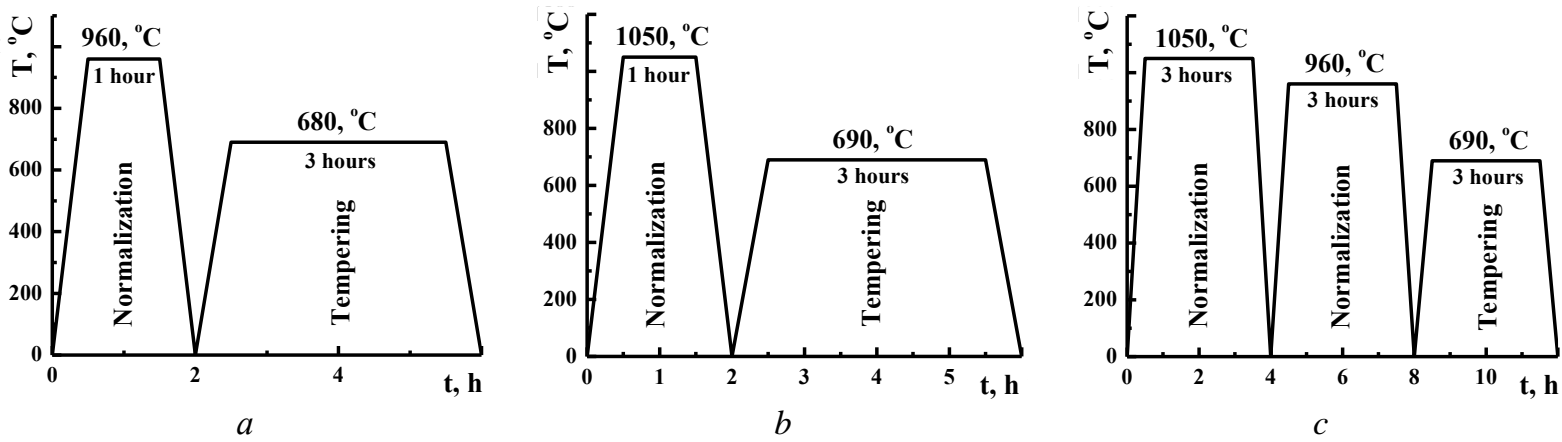

Figure 2. Changing of the temperature during restoration heat treatment according to modes $1(a), 2(b)$ and $3(c)$ 
Quantitative characteristics of the structure elements and $\mathrm{HB}$ hardness of the 25Kh2M1F steel. The main structural characteristics that are used to estimate the structural changes in metal are considered to be the average values of the grain size $D$ and the $d_{s}$ carbides. They were determined by both the cross-section method, and by means of computer program [27, 28].

From the analysis of results of the average grain size $D$ and $d_{s}$ carbides determination, it was concluded that due to the use of restoration HT according to any mode, the sizes of both grains and carbides in the steel structure decreased (Figures 3a,b). But the maximum reduction was reached by applying double normalization according to mode 3 . In this case, the grain sizes in the structure of the treated steel are decreased by $\sim 50 \%$, and carbides - by $\sim 65 \%$ compared to the operating steel $25 \mathrm{Kh} 2 \mathrm{M} 1 \Phi$.

Due to such structural transformations, the composition of steel $25 \mathrm{Kh} 2 \mathrm{M} 1 \mathrm{~F}$ ferrite matrix significantly changed, in comparison with the operating one. The doping elements (chromium and molybdenum) from large carbides transformed into the solid solution and strengthened the ferrite matrix.
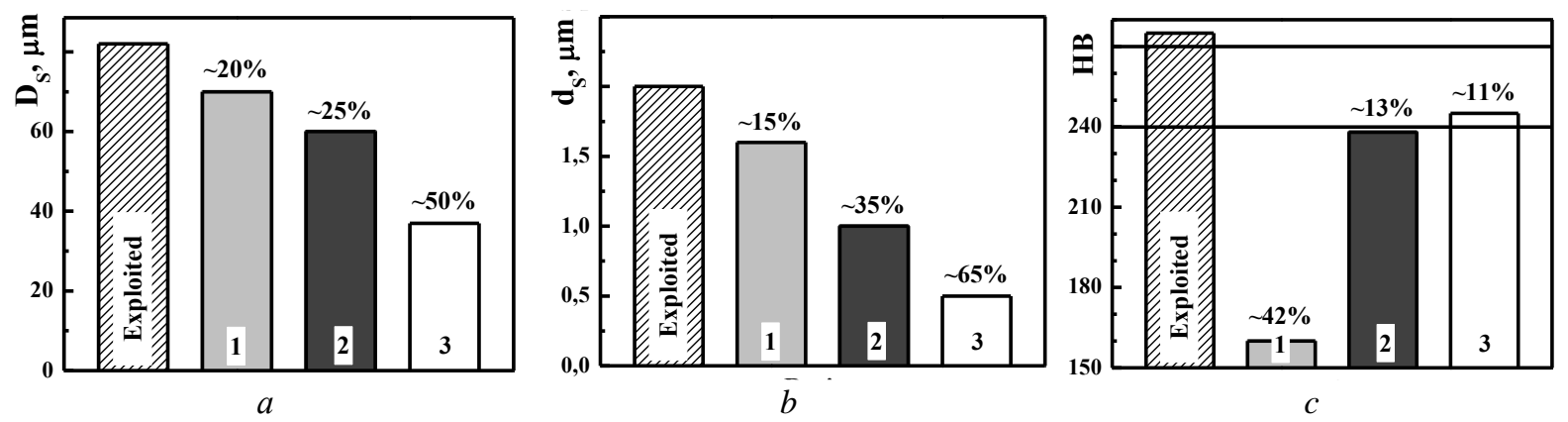

Figure 3. The average values of the grains sizes $D_{s}$ (a) and carbides $d_{s}$ (b) in the structure of steel $25 \mathrm{Kh} 2 \mathrm{M} 1 \mathrm{~F}$ and its hardness HB after operation and after its restoration according to different HT modes $(1,2,3)$. Numbers above the bars indicate the values (in the percentages) characterizing $D_{s}, d_{s}$ decrease and HB hardness after steel relatively to its characteristics after its operation

Having analyzed the steel hardness after $\sim 21 \cdot 10^{4}$ hours of operation in HPC case of TPP steam turbine, a significant nut metal strengthening was determined (Fig. $3 c$ ). Its hardness even went beyond the specified limits. Steel hardening was associated with excessive nut heating, which is provided by mounting or disassembling technology of HPC case cover of HPP steam turbine, and their subsequent sub-hardening during cooling.

After HT of the samples from the operating nut according to all modes, the steel hardness decreased (Fig. 3 c). Particularly, after HT according to mode 1, its hardness decreased by more than $\sim 40 \%$ and became significantly lower than the minimum permissible value, and after the HT according to mode 2, the steel hardness practically reached the lower limit of the specified range (Fig. $3 \mathrm{c}$ ). The use of metal double normalization made it possible to obtain the most optimal hardness, which is included in the specified range (Fig. $3 \mathrm{c}$ ) corresponding the smallest grain and carbide sizes along their boundaries.

Strength and plasticity characteristics of the $25 \mathrm{Kh} 2 \mathrm{M1F}$ steel. The efficiency of the repeated HT for properties restoration of steel from the nut, which ensure its operational workability at the beginning of operation, was checked using the above three mentioned HT modes of maintenance.

As the result of structural changes in the $25 \mathrm{Kh} 2 \mathrm{M} 1 \mathrm{~F}$ steel caused by nut operation conditions of, its strength characteristics increased (Fig. $4 a, b$ ) corresponding to the increase of the operating steel hardness, and plasticity (Fig. $4 c, d$ ) decreased to the level lower than the specified one, possible during sub-hardening of nuts in the air during assembly operations. 


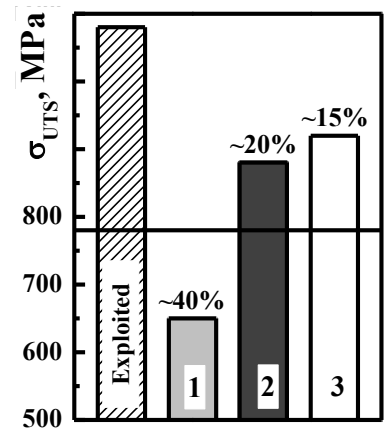

$a$

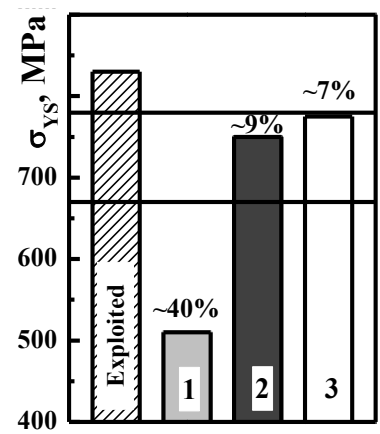

$b$

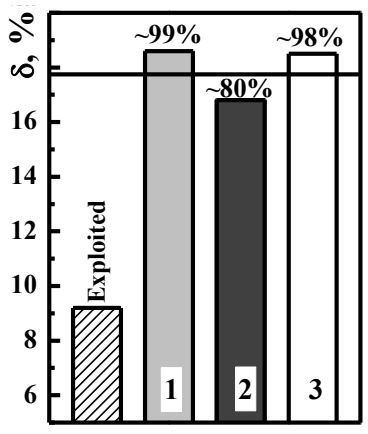

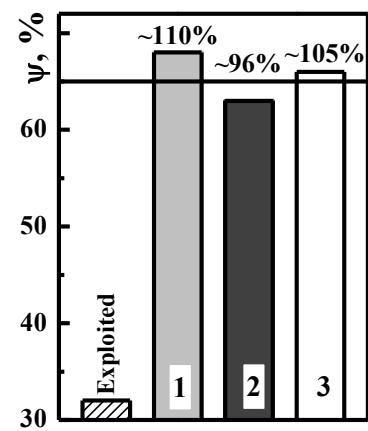

$d$

Figure 4. Tensile characteristics of $25 \mathrm{Kh} 2 \mathrm{M} 1 \mathrm{~F}$ steel after $\sim 21 \cdot 10^{4} \mathrm{~h}$ of operation in the nut of the high-pressure cylinder case of HPP steam turbine and after subsequent recovery according to three heat treatment modes $(1,2,3)$. The horizontal lines in the figure indicate the specified ranges of change or the smallest permissible value of mechanical characteristics of this steel for such elements. The numbers (in a percentage) above the bars indicate the effect of HT on the change in these characteristics relatively to the corresponding values for the operating steel

After the samples from the nut HT according the mode 1, the steel strength characteristics decreased by $\sim 40 \%$ and became lower than the specified values (Fig. $4 a, b$ ). At the same time, the plasticity characteristics increased by $\sim 2$ times (Fig. $4 c, d$ ). With the use of mode 2 the steel strength significantly increased, meeting the requirements of the regulation, but plasticity went beyond the specified values. And only using HT according to mode 3 it was possible to obtain the characteristics that gave reasons to recommend this mode for restoration of the operating nut properties. Since the characteristics of the recovered steel strength and plasticity corresponded to the values specified for this steel.

Impact toughness of the $25 \mathrm{Kh} 2 \mathrm{M} 1 \mathrm{~F}$ steel. The positive effect of the restoration HT was the most strongly manifested in the impact toughness test of (Fig. 5).

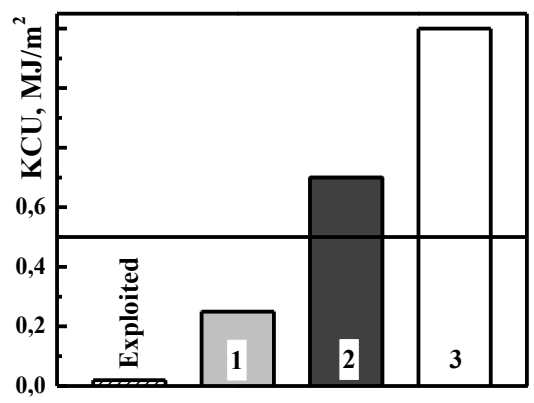

Figure 5. Impact toughness KCU of $25 \mathrm{Kh} 2 \mathrm{M} 1 \mathrm{~F}$ steel in nut after operation and restoration HT according to three modes $(1,2,3)$. The minimum permissible value of KCU for this steel in such fasteners is shown by horizontal lines

If, after operation, the brittle resistance of metal from the nut was critically low, then after HT according to mode 1, the impact toughness increased twice, but did not reach the specified level. After HT according to mode 2, the impact toughness of the nuts samples increased by 6 times and exceeded the specified level. At the same time, after double normalization according to mode 3 , the steel impact toughness increased additionally by 10 times relatively to the values for the operating steel, and steel plasticity characteristics were restored to the specified levels (Fig. 5).

Mechanical characteristics ranking. The certain mechanical and structural characteristics of the $25 \mathrm{X} 2 \mathrm{M} 1 \mathrm{~F}$ steel from the nut after operation and restoration HT according to mode 3 relatively to its corresponding characteristics in the initial state were compared (Fig. 6). Relative change of characteristics was determined by the ratio $\lambda=\left(\left(P_{\operatorname{expl}(H T)-}\right.\right.$ $\left.\mathrm{P}_{\text {initial }} / \mathrm{P}_{\text {initial }}\right) \times 100 \%$, where $\left.P_{\operatorname{expl}(H T)}\right)$ is the value of the analyzed mechanical characteristic of 
the operating steel (or after HT according to mode 3 ); $P_{\text {initial }}$ is the value of the corresponding steel characteristic in the initial state (according to Table 2).

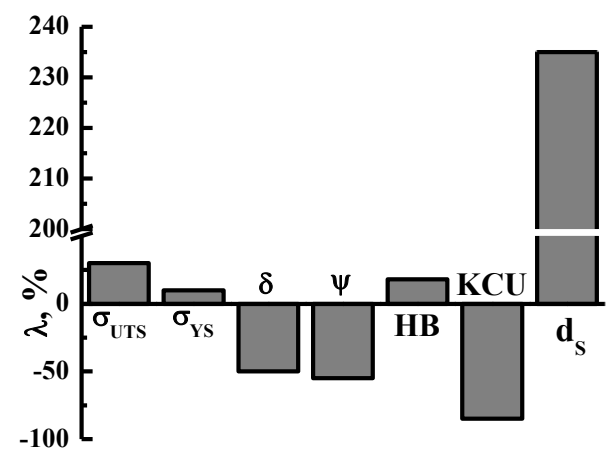

$a$

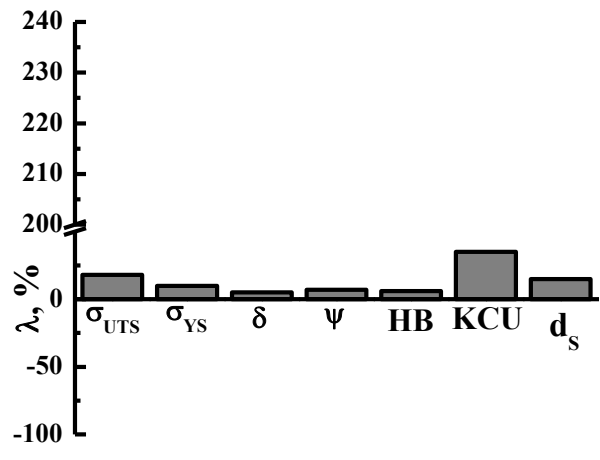

$b$

Fugure 6. Ranking of the mechanical characteristics of $25 \mathrm{Kh} 2 \mathrm{M} 1 \mathrm{~F}$ steel from the nut after operation $(a)$ and after restoration heat treatment according to mode $3(b)$ relatively to the corresponding characteristics of this steel in the initial state

Thus, the degradation effect (the increasing of strength characteristics, the reduction of plasticity and impact toughness, and the significant increase in the size of carbides, which were allocated along the grain boundaries, leaning the matrix phase on the doping elements content in it) of the operating steel relatively to the non-operating one is illustrated (Fig. $6 a$ ).

At the same time, on the example of HT according to mode 3 (Fig. $6 b$ ), the effect of the steel characteristics restoration is shown, which has the most strong influence on plasticity and impact toughness of steel $25 \mathrm{Kh} 2 \mathrm{M} 1 \mathrm{~F}$. Moreover, the relation of such change with the carbides size in the steel structure is evident. After all, the largest average size of carbides in the steel structure corresponds to the worst mechanical characteristics, and the smallest one respectively, the largest.

Hence, after double normalization of steel from the stud the uniform structure with equiaxed and the smallest in size grains and with the smallest carbides, the hardness was completely restored, and strength and plasticity characteristics met the specified requirements was obtained. This gave reasons to recommend double normalization for restoration of the operating $25 \mathrm{Kh} 2 \mathrm{M} 1 \mathrm{~F}$ steel characteristics and extend the nuts service life.

Conclusions. 1. A significant increase in grain size, intensive allocation of carbide along the grains boundaries and their coagulation with the decrease in the doping elements content (chromium, molybdenum) in the solid solution were determined in $25 \mathrm{Kh} 2 \mathrm{M} 1 \mathrm{~F}$ steel after $\sim 21 \cdot 10^{4}$ hours of its operation in the nut of HPC case of HPP steam turbine. It was considered as structural features of steel operation degradation, which affect metal resistance to load action at high operating temperatures.

It was shown that mechanical characteristics of $25 \mathrm{Kh} 2 \mathrm{M} 1 \mathrm{~F}$ steel after $\sim 21 \cdot 10^{4}$ hours operation were no longer correspond to the requirements of specification documents. Particularly, the impact toughness decreased by more than $80 \%$, the strength characteristics $\left(\sigma_{B}\right.$ and $\sigma_{0,2}$ ) increased by $\sim 32 \%$ and $\sim 8 \%$, and the maximum plasticity properties reduction reached $\sim 60 \%$, indicating the metal operational degradation.

The possibility of double normalization use (at $1050^{\circ} \mathrm{C}$ and $960^{\circ} \mathrm{C}$ ) with the subsequent high-temperature tempering at $690^{\circ} \mathrm{C}$ of the operating $25 \mathrm{Kh} 2 \mathrm{M} 1 \mathrm{~F}$ steel for its mechanical characteristics restoration to the levels specified for the attachment fitting elements in the initial condition is substantiated. This proves the rationale for the use of heat treatment of the nuts operating in the HPC case of HPP steam turbine in order to extend their service lifetime (but only if cracks defects are not detected in them by non-destructive research methods). 


\section{References}

1. Laxminarayan K. M., Venkatarama Reddy, Kumar Optimization of Steam Turbine Casing for Static Loading Condition. Ijmsa. 2013. Vol. 1. No. 2. pp. 122-126. https://doi.org/10.12720/ijmse.1.2.122-126

2. Borodov Yu. M., Rodin V. N. Remont parovyih turbin: uchebnoe posob. / pod obschey red. Yu. M. Brodova, V. N. Rodina. Ekaterinburg: GOU UGTU - UPI, 2002. 203 p. [In Russian].

3. RD 153-34.1-39.603-99. Rukovodstvo po remontu armaturyi vyisokih parametrov. M.: SPO ORGRES, 2000. 68 p. [In Russian].

4. Molochek V. A. Remont parovyih turbin. Moskva: Energiya, 1968. 376 p. [In Russian].

5. GOST 20700-75 (ST SEV 1066-78). Boltyi, shpilki, gayki i shaybyi dlya flantsevih soedineniy s temperaturoy sredyi ot 0 do $650^{\circ}$ C. M.: Izdatelstvo standartov, 1981. 6 p. [In Russian].

6. Krechkovs'ka H. V. Strukturni zminy v ekspluatovaniy na holovnomu parohoni TES stali $15 \mathrm{Kh} 1 \mathrm{M} 1 \mathrm{~F}$, povyazani z zupynkamy tekhnolohichnoho protsesu. Metallofyzyka y noveyshye tekhnolohyy. 2008. T. 30. Spetsvyp. P. 701-711. [In Ukrainian].

7. V. V. Panasyuk, H. M. Nykyforchyn, O. Z. Student, Z. V. Slobodyan Zastosuvannya pidkhodiv mekhaniky ruynuvannya do otsinky vodnevoyi dehradatsiyi staley nafto- ta paroprovodiv. Mekhanika i fizyka ruynuvannya budivel'nykh materialiv ta konstruktsiy: zb. nauk. prats'. L'viv: Kamenyar, 2002. Vyp. 5. Pp. 537-546. [In Ukrainian].

8. O. Z. Student, H. V. Krechkovs'ka, T. E. Palashchuk et al. Influence of the long-term operation of $12 \mathrm{Kh} 1 \mathrm{MF}$ steel of the bends of main steam pipelines of thermal power plants on its mechanical properties. Materials Science. 2018. Vol. 53. Iss. 4. Pp. 1-8. https://doi.org/10.1007/s11003-018-0095-1

9. Yu. K. Petrenya i dr. Obespechenie prochnosti i resursa energooborudovaniya - vazhneyshee napravlenie issledovaniy i razrabotok OAO "NPO TsKTI im. I. I. Polzunova”. Nadezhnost i bezopasnost energetiki. 2008. No. 1. P. 14-19. [In Russian].

10. Rezinskih V. F., Grin E. A., Zlepko V. F. Kontseptsiya prodleniya resursa metalla oborudovaniya TES. Promyishlennaya energetika. 2002. No. 4. P. 25-29. [In Russian].

11. Lebedev V. I., Oreshkin B. M., Sudakov A. V. Prodlenie resursa oborudovaniya energoblokov AES. Tr. TsKTI. 2002. Vyp. 282. P. 28-44. [In Russian]. https://doi.org/10.2753/RES1060-939344086

12. Savostyanova L. V., Litvak V. V. Analiz neispravnostey elementov turboustanovki. Elektricheskie stantsii. 2012. No. 4. P. 18-21. [In Russian].

13. Caudill M. B., Griebenov R. D. Analysis of Leakage Between HP and IP Turbines Using PEPSE. URL: http://famos.scientech.us/Papers/1990/1990section3.pdf (Last accessed: 16.01.2019).

14. Hopson W. H. Practical Field Experience with Steam Turbine Performance Testing - EPRI Heat Rate Improvement Conference, 2003.

15. RD 10-262-98 (RD 153-34.1-17.421-98). Tipovaya instruktsiya po kontrolyu metalla i prodleniyu sroka sluzhbyi osnovnyih elementov kotlov, turbin i truboprovodov teplovyih elektrostantsiy. M.: RAO "EES Rossii", 1999. 93 p. [In Russian].

16. GOST 1497-84 Metallyi. Metodyi ispyitaniy na rastyazhenie. M.: Standartinform, 2006. 22 p. [In Russian].

17. GOST 9012-59 Metallyi. Metod izmereniya tverdosti po Brinellyu. Moskva: Standartinform, 2008. 40 p. [In Russian].

18. GOST 9454-78 Metallyi. Metod ispyitaniya na udarnyiy izgib pri ponizhennyih, komnatnoy i povyishennyih temperaturah. M.: Izdatelstvo standartov, 2008. 12 p. [In Russian].

19. Svirska L. M. Vikoristannya termichnogo obroblennya dlya vidnovlennya robotozdatnostI krIpilnoYi armaturi tsilIndrIv visokogo tisku parovoYi turbIni TES. Metallofizika i noveyshie tehnologii. 2008. Vol. 30. Spetsvip. Pp. 689-700. [In Ukrainian].

20. H. M. Nykyforchyn, O. Z. Student, H. V. Krechkovs'ka et al. Evaluation of the influence of shutdowns of a technological process on changes in the in-service state of the metal of main steam pipelines of thermal power plants. Materials Science. 2010. Vol. 46. No. 2. Pp. 177-189. https://doi.org/10.1007/s11003-010-9288-y

21. O. Z. Student. Accelerated method for hydrogen degradation of structural steel. Ibid. 1998. Vol. 34 . No. 4. Pp. 497-507. https://doi.org/10.1007/BF02360701

22. O. P. Ostash, A. I. Kondyr, O. V. Vol'demarov et al. Structural microdamageability of steels of the steam pipelines of thermal power plants. Ibid. 2009. T. 45. № 3. Pp 340-349. https://doi.org/10.1007/s11003-009-9189-0

23. I. R. Dzioba. Properties of $13 \mathrm{KhMF}$ steel after operation and degradation under the laboratory conditions. Ibid. 2010. Vol. 46. No. 3. Pp. 357-364. https://doi.org/10.1007/s11003-010-9297-x

24. O. P. Ostash, O. V. Vol'demarov, P. V. Hladysh et al. Evaluation of the degradation of steels of steam pipelines according to their structural, mechanical, and electrochemical characteristics. Ibid. 2011. Vol. 46. No. 4. Pp. 431-439. https://doi.org/10.1007/s11003-011-9309-5

25. O. Z. Student, L. M. Svirs'ka, I. R. Dzioba Influence of the long-term operation of $12 \mathrm{Kh} 1 \mathrm{M} 1 \mathrm{~F}$ steel from different zones of a bend of steam pipeline of a thermal power plant on its mechanical characteristics. Ibid. 2012. Vol. 48. Iss. 2. Pp. 239-246. https://doi.org/10.1007/s11003-012-9498-6

26. Student O. Z., Krechkovs'ka H. V. Anisotropy of the mechanical properties of degraded 15Kh1M1F steel after its operation in steam pipelines of thermal power plants. Ibid. 2012. Vol. 47. Iss 5. Pp. 590-597. https://doi.org/10.1007/s11003-012-9432-y

27. I. M. Zhuravel', L. M. Svirs'ka. Measurement of the mean grain size in a metal by using fractal dimensions. Ibid. 2010. Vol. 467. Iss. 3. Pp. 418-420. https://doi.org/10.1007/s11003-010-9306-0 
28. R. A. Vorobel', I. M. Zhuravel', L. M. Svirs'ka et al. Automatic selection and quantitative analysis of carbides on grain boundaries of $12 \mathrm{Kh} 1 \mathrm{MF}$ steel after operation at a steam pipeline of a thermal power plant. Ibid. 2011. Vol. 47. Iss. 3. Pp. 393-400. https://doi.org/10.1007/s11003-011-9408-3

\section{Список використаної літератури}

1. Laxminarayan K. M., Venkatarama Reddy, Kumar Optimization of Steam Turbine Casing for Static Loading Condition. Ijmsa. 2013. Vol. 1. No. 2. P. 122-126. https://doi.org/10.12720/ijmse.1.2.122-126

2. Бородов Ю. М., Родин В.Н. Ремонт паровых турбин: учебное пособ./ под общей ред. Ю. М. Бродова, В. Н. Родина. Екатеринбург: ГОУ УГТУ - УПИ, 2002. 203 с.

3. РД 153-34.1-39.603-99. Руководство по ремонту арматуры высоких параметров. М.: СПО ОРГРЭС, 2000. $68 \mathrm{c}$.

4. Молочек В. А. Ремонт паровых турбин. Москва: Энергия, 1968. 376 с

5. ГОСТ 20700-75 (СТ СЭВ 1066-78). Болты, шпильки, гайки и шайбы для фланцевих соединений с температурой среды от 0 до $650^{\circ} \mathrm{C}$. М.: Издательство стандартов, 1981. 6 с.

6. Кречковська Г. В. Структурні зміни в експлуатованій на головному парогоні ТЕС сталі 15Х1M1Ф, пов'язані з зупинками технологічного процесу. Металлофизика и новейшие технологии. 2008. Т. 30. Спецвип. С. 701-711.

7. Застосування підходів механіки руйнування до оцінки водневої деградації сталей нафто- та паропроводів. Механіка і фізика руйнування будівельних матеріалів та конструкцій: зб. наук. праць / В. В. Панасюк, Г. М. Никифорчин, О. 3. Студент та ін.; Львів: Каменяр, 2002. Вип. 5. С. 537-546.

8. O. Z. Student, H. V. Krechkovs'ka, T. E. Palashchuk et al. Influence of the long-term operation of $12 \mathrm{Kh} 1 \mathrm{MF}$ steel of the bends of main steam pipelines of thermal power plants on its mechanical properties. Materials Science. 2018. Vol. 53. Iss. 4. Pp. 1-8. https://doi.org/10.1007/s11003-018-0095-1

9. Петреня Ю.К. и др. Обеспечение прочности и ресурса энергооборудования - важнейшее направление исследований и разработок ОАО «НПО ЦКТИ им. И. И. Ползунова». Надежность и безопасность энергетики. 2008. № 1. С. 14-19.

10. Резинских В. Ф., Гринь Е. А., Злепко В. Ф. Концепция продления ресурса металла оборудования ТЭС. Промышленная энергетика. 2002. № 4. С. 25-29.

11. Лебедев В. И., Орешкин Б. М., Судаков А. В. Продление ресурса оборудования энергоблоков АЭС. Тр. ЦКТИ. 2002. Вып. 282. С. 28-44. https://doi.org/ 10.2753/RES1060-939344086

12. Савостьянова Л. В., Литвак В. В. Анализ неисправностей элементов турбоустановки. Электрические станции. 2012. № 4. С. 18-21.

13. Caudill M. B., Griebenov R. D. Analysis of Leakage Between HP and IP Turbines Using PEPSE. URL: http://famos.scientech.us/Papers/1990/1990section3.pdf (Last accessed: 16.01.2019).

14. Hopson W. H. Practical Field Experience with Steam Turbine Performance Testing - EPRI Heat Rate Improvement Conference, 2003.

15. РД 10-262-98 (РД 153-34.1-17.421-98). Типовая инструкция по контролю металла и продлению срока службы основных элементов котлов, турбин и трубопроводов тепловых электростанций М.: РАО «ЕЭС России», 1999. 93 с.

16. ГОСТ 1497-84 Металлы. Методы испытаний на растяжение. Москва: Стандартинформ, 2006. $22 \mathrm{c}$.

17. ГОСТ 9012-59 Металлы. Метод измерения твердости по Бринеллю. Москва: Стандартинформ, 2008. $40 \mathrm{c}$.

18. ГОСТ 9454-78 Металлы. Метод испытания на ударный изгиб при пониженных, комнатной и повышенных температурах. Москва: Издательство стандартов, 2008. 12 с.

19. Свірська Л. М. Використання термічного оброблення для відновлення робото здатності кріпильної арматури циліндрів високого тиску парової турбіни ТЕС. Металлофизика и новейшие технологии. 2008. Т. 30. Спецвип. С. 689-700.

20. H. M. Nykyforchyn, O. Z. Student, H. V. Krechkovs'ka et al. Evaluation of the influence of shutdowns of a technological process on changes in the in-service state of the metal of main steam pipelines of thermal power plants. Materials Science. 2010. Vol. 46, No. 2. Pp. 177-189. https://doi.org/10.1007/s11003-010-9288-y

21. O. Z. Student. Accelerated method for hydrogen degradation of structural steel. Ibid. 1998. Vol. 34, No. 4. Pp. 497-507. https://doi.org/10.1007/BF02360701

22. O. P. Ostash, A. I. Kondyr, O. V. Vol'demarov et al. Structural microdamageability of steels of the steam pipelines of thermal power plants. Ibid. 2009. T. 45. № 3. Pp 340-349. https://doi.org/10.1007/s1 1003-0099189-0

23. R. Dzioba. Properties of $13 \mathrm{KhMF}$ steel after operation and degradation under the laboratory conditions. Ibid. 2010. Vol. 46. No. 3. Pp. 357-364. https://doi.org/10.1007/s11003-010-9297-X

24. O. P. Ostash, O. V. Vol'demarov, P. V. Hladysh et al. Evaluation of the degradation of steels of steam pipelines according to their structural, mechanical, and electrochemical characteristics. Ibid. 2011. Vol. 46. No. 4. Pp. 431-439. https://doi.org/10.1007/s11003-011-9309-5 
25. O. Z. Student, L. M. Svirs'ka, I. R. Dzioba. Influence of the long-term operation of 12Kh1M1F steel from different zones of a bend of steam pipeline of a thermal power plant on its mechanical characteristics. Ibid. 2012. Vol. 48. Iss. 2. Pp. 239-246. https://doi.org/10.1007/s11003-012-9498-6

26. Student O. Z., Krechkovs'ka H. V. Anisotropy of the mechanical properties of degraded $15 \mathrm{Kh} 1 \mathrm{M} 1 \mathrm{~F}$ steel after its operation in steam pipelines of thermal power plants. Ibid. 2012. Vol. 47. Iss 5. Pp. 590-597. https://doi.org/10.1007/s11003-012-9432-y

27. M. Zhuravel', L. M. Svirs'ka. Measurement of the mean grain size in a metal by using fractal dimensions. Ibid. 2010. Vol. 467. Iss. 3. Pp. 418-420. https://doi.org/10.1007/s11003-010-9306-0

28. R. A. Vorobel', I. M. Zhuravel', L. M. Svirs'ka et al. Automatic selection and quantitative analysis of carbides on grain boundaries of $12 \mathrm{Kh} 1 \mathrm{MF}$ steel after operation at a steam pipeline of a thermal power plant. Ibid. 2011. Vol. 47. Iss. 3. Pp. 393-400. https://doi.org/10.1007/s11003-011-9408-3

\title{
УДК 621.311:621.882.626
}

\section{ВІДНОВЛЕННЯ РОБОТОЗДАТНОСТІ ЕКСПЛУАТОВАНИХ ЕЛЕМЕНТІВ КРІПЛЕННЯ КОРПУСУ ЦВТ ПАРОВИХ ТУРБІН}

\section{Леся Свірська}

\author{
Фізико-механічний інститут ім. Г. В. Карпенка НАН України, \\ Львів, Украӥна
}

\begin{abstract}
Резюме. Кріпильні елементи відносять до достатньо дорогих та відповідальних елементів, адже їх пошкодження у процесі експлуатації загрожує персоналу та довкіллю, може спричинити масштабні руйнування станційного устаткування $і$ завдати значних економічних втрат. Механічні характеристики (твердість, міџність, пластичність і ударна в'язкість) сталі кріпильної арматури циліндра високого тиску (ЦВТ) парової турбіни ТЕС, експлуатованої впродовж $21 \times 10^{4}$ год. за впливу жорстких температурно-силових умов, вийшли за межі регламентованих значень, щуо є ознакою експлуатаційної деградаиї металу. Зокрема, ударна в'язкість зразків з металу експлуатованої гайки знизилася на понад $80 \%$, характеристики міџності $\left(\sigma_{B} i \sigma_{0,2}\right)$ зросли відповідно на $\sim 32 \% i \sim 8 \%$, а характеристики пластичності знизилися на 60\%. У зв'язку з иим виникла потреба обгрунтувати можливість продовження ресурсу експлуатованих елементів кріплення корпусних частин ЦВТ парової турбіни, в яких методами візуального обстеження та неруйнівного контролю не виявлено дефектів. Це дало б змогу відтермінувати їх заміну в часі експлуатації.

Для відновлення роботоздатності експлуатованих гайок використали повторне термічне оброблення (ТО) зразків. Оскільки для гайок зі сталі 25X2M1Ф використовують нормалізацію і високий відпуск, як базові для забезпечення необхідних механічних характеристик ій у вихідному стані, то $і$ для повторного ТО використали нормалізацію. Апробували три варіанти нормалізації сталі (від 960 $1050^{\circ} \mathrm{C}$ і подвійну від $1050^{\circ} \mathrm{C}$ i $960^{\circ} \mathrm{C}$ ) з подальшим відпуском за температури $690^{\circ} \mathrm{C}$. Проте після комплексу досліджень виявили, щзо твердість, характеристики міцнооті $i$ пластичності та опір крихкому руйнуванню металу з гайки вдалося відновити до регламентованих значень лише за використання подвійної нормалізації. Зокрема, ударна в'язкість сталі з гайки зросла у 12 разів, характеристики міцності металу гайки знизилися, а пластичності - підвищилися до регламентованих рівнів. Отримані результати дали змогу обтрунтувати доцільність використання ТО для відновлення механічних характеристик сталі гайок ЦВТ парових турбін ТЕС, у яких неруйнівними методами досліджень не виявлено тріщиноподібних дефектів. Це дає підстави рекомендувати відновлювальну ТО для продовження ресурсу гайок після їх тривалої експлуатації зі втратою металу регламентованих характеристик.
\end{abstract}

Ключові слова: кріпильні елементи, деградація металу, структура, характеристики міцності й пластичності, відновлення роботоздатності. 